INDEPENDENT JOURNAL OF MANAGEMENT \& PRODUCTION (IJM\&P)

http://www.ijmp.jor.br

v. 5, n. 2, February - May 2014.

ISSN: 2236-269X

DOI: 10.14807/ijmp.v5i2.134

\title{
STRATEGIES FOR INCREASING PRODUCTIVITY IN PRODUCTION
} SYSTEMS

\author{
Diego Augusto de Jesus Pacheco \\ University Federal of Rio Grande do Sul, UFRGS - Brazil \\ E-mail: profdajp@gmail.com \\ Isaac Pergher \\ FTEC, Caxias do Sul- Brazil \\ E-mail: isaacpergher@ftec.com.br
}

Carlos Fernando Jung Faculdades Integradas de Taquara, FACCAT - Brazil

E-mail: carlosfernandojung@gmail.com

Carla Scwenberg ten Caten University Federal of Rio Grande do Sul, UFRGS - Brazil E-mail: tencaten@producao.ufrgs.br

Submission: 11/09/2013

Revision: 25/09/2013

Accept: 19/10/2013

\section{ABSTRACT}

The main objective of this article is to point a set of practical strategies that can be adopted to increase the capacity of constraints resources on production systems, when the constraint is inside the factory and not is in the market. To serve this purpose will be presented strategies based on best practices of the Theory of Constraints, Lean Manufacturing and Total Productive Maintenance. This article also presents the mains tools for the deployment of these methodologies. The survey results have provided an objective set of practical strategy that can be used to increase the capacity and productivity of production systems according to the needs of each manufacturing system.

Keywords: Capacity; Theory of the Constraints; Total Productive Maintenance; Lean Manufacturing; Productivity. 
INDEPENDENT JOURNAL OF MANAGEMENT \& PRODUCTION (IJM\&P)

http://www.ijmp.jor.br

v. 5, n. 2, February - May 2014.

ISSN: 2236-269X

DOI: 10.14807/ijmp.v5i2.134

\section{INTRODUCTION}

Hayes et al. (2008) argue that to measure the capacity of productive systems it is a complex task, due to action of the following factors: politics of the company, trustworthiness of the suppliers, trustworthiness of the equipment, taxes of production, impact of the human factors and variability. For Hopp and Spearman (2001) the variability exists in all the production systems and can cause great impact in the performance of capacity. For this reason, the ability to measure, to understand and to manage becomes it critical for an efficient administration of the production. Aiming at to manage and to raise the capacity of manufacture systems, this article investigates the contributions that can offer Theory of Constraints (TOC), Total Productive Maintenance (TPM), Lean Manufacturing and its elements.

The integrated use of the Theory of Constraints with the Lean comes being argued for some authors as Dettmer (2001), Antunes (1998), Scheinkopf and Moore (2004), Sproull (2009) and Pacheco (2013;2014). Dettmer (2001) for instance, indicated the following points of similarity between the two approaches: they possess the common objective to increase profits, the value is defined by the customer, the factor quality is essential for both, they aim at the reduction of the lots of production, search the flow, the increase of the capacity continuous, the minimization of the inventory and the participation of the work force fulfill excellent paper in the success of the unfolding of the method and the tools.

Bonal et al. (1996) had shown that the integrated use of the TOC and the TPM results in a boarding of increase of the financial results of an organization, from the increase of the efficiency and the capacity of the productive passes. Ed Rose et. al (1995) presented the following benefits of the integrated use of the TOC and the TPM to raise the capacity of systems: i) with the identification of the restrictive equipment using the TOC, a directed teams of TPM can itself be created to decide to take its performance; ii) when identifying the pass, the next resource also must be analyzed to reduce the losses of the productive flow; iii) it is possible to add to the TPM an improvement program contend other approaches (5S, visual control, fast exchange of tools, analysis of stops of machines, etc.) that they contribute to raise the capacity of the bottleneck.

Having in sight the above-mentioned points of convergence, it is viable to think about the unification of the two techniques in quarrel guided to raise capacity of 
INDEPENDENT JOURNAL OF MANAGEMENT \& PRODUCTION (IJM\&P)

http://www.ijmp.jor.br

v. 5, n. 2, February - May 2014.

ISSN: 2236-269X

DOI: 10.14807/iimp.v5i2.134

productive systems. Being thus, the present article will go to explore this analysis being aimed at to present a set of extracted strategies of TOC, Lean and TPM.

\section{TOYOTA SYSTEM OF PROUCTION (TPS): THE DNA OF LEAN}

With intense global competition, firms strive to provide their customers with highly valued products and services. Demanding customers expected these firms to integrate complex sets of requirements in terms of outstanding quality, competitive prices, reliable delivery and innovative features (TOMINO et al., 2009). In this context, the lean philosophy is growing and invading companies in the West. Currently, there is a great search of the concepts of Lean Manufacturing by Western companies, considering the needs become more competitive, based on the benefits that the TPS can provide, considering the performance of Japanese companies (SCHONBERGER, 2007). The TPS are often articulated with mandates such as eliminating waste, rooting out defects and reducing lead times. (JAYARAM; DAS; NICOLAE, 2010).

Developed in Toyota plants in Japan by Sakichi Toyoda, Kiichiro Toyoda, Taiichi Ohno and Shigeo Shingo, this system consists of several tools, among which are highlighted: Quick Change Tool, Kanban, Poka Yoke, 5S, standardization activity work, Preventive Maintenance and manufacturing cells, focused on two basic STP, Automation (or automation with a human touch) and Just-in-time (JIT), as Ohno (1997). The pillar JIT, Kanban is intended to send the information necessary for the operation of the entire system (OHNO, 1997), however, the JIT is not feasible without the support of the concept of Automation/Zero Defect, because in this case the materials could arrive at the right amount, at the right place at the right time, however, with inadequate quality. The STP philosophy has been applied in many different areas as: Health (SEREMBUS; MELOY; POSMONTIER, 2012; STAPLETON et al., 2009); Product development (WANG, CONBOY, CAWLEY, 2012); and Logistics (KANEKO; NOJIRI, 2008; HAAN; NAUS; OVERBOOM, 2012).

As Shingo (1996b) the production systems can be understood by the logic of the Mechanism of Function Production (MFP). In the logic of the MFP the production constitutes a net of processes and operations or phenomena that if locate throughout axes that if divide in parts. In the concept of production of Shingo (1996a), the MFP can be understood according as: i) function process: the flow of products between 
INDEPENDENT JOURNAL OF MANAGEMENT \& PRODUCTION (IJM\&P)

http://www.ijmp.jor.br

v. 5, n. 2, February - May 2014.

ISSN: 2236-269X

DOI: 10.14807/iimp.v5i2.134

the operations in the time and the space, that is, materials, tasks, ideas; ii) function operation: the flow of the citizen of works in the time and the space, that is, the operators and the machines. Shingo (1996b) affirms that the priority of the production improvements, must be given to the function process and thus being the strategies presented in this work to raise the capacity of productive systems are related to the function process.

According Ghinato (1996) the TPS has been more recently, referenced as "Lean Production System". The term "Lean" was created originally in the book "The Machine that Changed the World" of Womack, Jones and Roos (1990), as resulted of an ample study on the world-wide automobile industry carried through by the MIT in which it proved the advantages in the use of the TPS. The study it evidenced that the TPS provided to expressive differences in relation to the productivity, quality, development of products and explained the success of the Japanese industry at the time. In this direction, the 5 principles of the Lean, as Womack and Jones (1996) and Rother and Shook (1998) are: i) Necessarily to specify the value for specific product; ii) To identify the flow of value for each product; iii) It makes the value to flow without interruptions; iv) To pull; v) To search the perfection.

\section{TOTAL PRODUCTIVE MAINTENANCE (TPM)}

For Nakajima (1988) the measures of Index of Operational Income Global (IROG) must be considered as an operational indicator and can inside be applied in diverse levels of a manufacture system. It can be used with benchmark to measure the level of performance of a productive system of global form. That is, the IROG is measured initially and compared with an IROG future after the system to have passed for a program of improvements or then compared with the performance of other similar systems. It can be calculated in systems of manufacture with diverse lines of production, providing to verify which the real levels of use of the assets of the industry.

The IROG can individually be calculated in machines, making possible to identify which machines they possess high performance or low (in relation to one given goal), thus directing the focus of action of the TPM with one all. The quarrel of the IROG is central for the calculation of the capacity because it determines the 
practical capacity and not theoretician of the equipment and systems. Equation 1 presents the generic equation of calculation of the IROG:

$\boldsymbol{U}_{(\text {overall })=}=\frac{\sum_{\mathrm{i}=1}^{\mathrm{N}} \text { tpi } \times \mathrm{qi}}{\mathrm{T}}$

Where:

tp: it is the time of cycle or time standard of product $X$;

$\mathrm{q}$ : it is the amount of processed products $\mathrm{X}$;

$\mathrm{T}$ : it is the available time for production.

It is verified in this equation, that the multiplication of the time of cycle of a product for the produced amount of this product in one determined equipment corresponds to the time of aggregation of value of this equipment in the production process on the practical prism of lean practices (ANTUNES, 1998). The calculation of the IROG is made considering the following aspects: if the work rank is a resource pass, in this in case the measures IROG is called TEEP (Total Effective Equipment Productivity) and if the work rank is a resource not pass, in this in this case, the IROG is called of OEE (Overall Equipment Efficiency). The considerations above consist of the calculation of the global efficiency of the equipment traverse of the general equation, having to be unfolded, as Nakajima (1988) with the purpose to identify the main causes of the inefficiencies observed in the workstation, in function of the following index of efficiency, as equation 2:

$\boldsymbol{U}_{(\text {overall })=\mu 1 \times \mu 2 \times \mu 3}$

Where:

$\mu 1$ : Index of Operational Time - ITO;

$\mu$ 2: Index of Operational Performance - IPO;

$\mu$ 3: Index of Approved Products - IPA.

ITO corresponds to the time where the equipment was available, abstaining the stops not coded. It is related, therefore, with the stoppage of the equipment. That 
INDEPENDENT JOURNAL OF MANAGEMENT \& PRODUCTION (IJM\&P)

http://www.ijmp.jor.br

v. 5, n. 2, February - May 2014.

ISSN: 2236-269X

DOI: 10.14807/iimp.v5i2.134

is, when the speed of the same falls the zero. The IPO measures the operational performance of the resource, being calculated in function of the available time and to the reduction of the speed of the same, of moment operation in emptiness and stops. It is related, therefore, with the fall of speed of the resource (nominal different speed of and the different one of zero). The last indicator analyzed is the IPA that measures the quality of the produced parts, being calculated in function of the real running time, abstaining the time expense with rubbish or working again. As Nakajima (1988) to raise the equipment capacity it is necessary to also control the following parameters:

a) Mean time between failures (MTBF): the arithmetic mean of the existing times, for repairable equipment and in functioning, enters the end of an imperfection and beginning of another imperfection, the next imperfection.

b) Mean time to repair (MTTR): the arithmetic mean of the times of repair of a system, an item or a equipment.

c) Availability (A) is the fraction of time the equipment is in operation, performing the function for which it was intended. Given by Equation 3 :

$A=\frac{M T B F}{M T B F+M T T R}$

\section{THEORY OF CONSTRAINTS (TOC)}

Theory of Constraints (TOC) was development by physics Eliyahu M. Goldratt and spread off through books, games and movies. Second Wong et al. (2009) TOC is a management philosophy to lead the organizations to get better results in terms of continuous improvement and goals. Different areas have been applying TOC (GOLDRATT, 2009; BEVILACQUA; CIARAPICA; GIACCHETTA, 2009; WU et al., 2010; LINHARES, 2009). The TOC can be understood from the following components according Antunes et al. (2008), Cox and Spencer (2002) and Mabin and Balderstone (2000):

a) The Logistic boarding and of Operations, that involve the following methods: the five steps involving the focus in the improvement of the processes, the process of programming of the production involving the management saw logic DBR (Drum, Buffer and Rope), the management of the buffers in the 
INDEPENDENT JOURNAL OF MANAGEMENT \& PRODUCTION (IJM\&P)

http://www.ijmp.jor.br

v. 5, n. 2, February - May 2014.

ISSN: 2236-269X

DOI: 10.14807/iimp.v5i2.134

productive system and the analysis of the productive systems adopting classification $\mathrm{V}-\mathrm{A}-\mathrm{T}$.

b) The proposal of a System of Measurements of Performance, that passes for: definition of the Profits, Inventories and Operational Expenses of the Company, Definition of the mix of products that will have to be produced aiming at to maximize the results and the logic of the Profits per day and the Inventories per day.

c) And finally, the TOC can be understood as a Thinking Process aiming at to the solution of problems that involves the following techniques: the Current Reality Tree (CRT), the Future Reality Tree (FRT), The Primary Requisite Tree (PRT), Transition Tree (TT) and the method of the Evaporation of Clouds.

Some examples of study to apply the TOC approach as DBR, System of Measurements of Performance, and Thinking Process in different environment are: Rossi Filho et al. (2012); Pergher, Rodrigues and Lacerda (2011); Georgiadi and Politou (2013). The quarrel of this article to raise the capacity will go to approach and to detail the 5 steps of the focus and method DBR of the TOC. Goldratt (1991) presents the five steps of the targeting process:

Identify the restriction of the system. It can be internal or external to the company. When the total demand of data mix of products is bigger of what the capacity of the plant says that a production pass has itself. However, when the production capacity is superior to the production demand the restriction is external to the productive system, that is, the restriction is related with the market and to the performance of the commercial area of the company.

Explore of the best possible form the restriction of the system. If the restriction is internal to the plant, the best decision consists of maximizing the profit in the pass. If she will be external to the system in data time, they do not exist passes in the plant and the profit will be limited by the restrictions of the market and to the sales performance of the company.

Subordinate all the too much resources to the decision taken in step 2. The logic of this step, independently of the external or internal restriction to be, consists of reducing to the maximum the operational inventories and expenditures and at the same time to guarantee the maximum theoretical profit of the production system. 
INDEPENDENT JOURNAL OF MANAGEMENT \& PRODUCTION (IJM\&P)

http://www.ijmp.jor.br

v. 5, n. 2, February - May 2014.

ISSN: 2236-269X

DOI: 10.14807/iimp.v5i2.134

Raise the capacity of the constraints. If the pass will be internal is necessary to increase its productive capacity. This can be made through changes of layout, equipment purchase, reduction of the variability, reduction of setup, etc. In this step, the Toyota Production System presents a series of tools and techniques of improvement that can be used, that they will not be argued by not being the focus of the analysis. Already the variability can be understood and be improved from the optics of the Factory Physics developed by Hopp and Spearman (2001, chapter 7 and 8).

Come back to step 1 not to leave that inertia takes account of the system. When raising the productive capacity of the restriction the system becomes, a priori, a generic system, what it generates the necessity to analyze it is again. Steps 4 and 5 they show the character of searched continuous improvement in the TOC, with the objective systematically to reach permanent and the global goal of the system: "to today generate profit and in the future".

The DBR aims at to operationalize in the factory the five steps of improvement of the processes of the TOC. To Georgiadis and Politou (2013), DBR approaches provide production managers with effective tools to manage production disruptions and improve operational performance. To Lee et al. (2010) DBR works effectively in typical job shop environments. Traditional DBR uses a three-buffer system to protect both the due-dates and detailed finite capacity schedule of the capacity constraint resources (CCR). This approach offers more protection than merely keeping the CCR from starvation as a result of delay on the non-constraint resources. Starvation is defined in TOC as the condition where the constraint resource is without work to perform. From a system perspective, if the constraint buffer is empty and the constraint is idle or starved, system throughput is lost (BETTERTON; COX, 2009).

TOC defines Throughput as the rate at which the system generates 'goal units'. According Watson, Blackstone and Gardiner (2007), the phase 'Explore of the best possible form the restriction of the system' seeks to achieve the highest rate of throughput possible within the confines of the system's current resources. The output of the system is limited by the rate of throughput at the constraint; therefore, the third step is to subordinate the system to the constraint. In this way, DBR uses the 'rope' to fit non-constraint resources according constraint resource production rate. 
INDEPENDENT JOURNAL OF MANAGEMENT \& PRODUCTION (IJM\&P)

http://www.ijmp.jor.br

v. 5, n. 2, February - May 2014.

ISSN: 2236-269X

DOI: 10.14807/iimp.v5i2.134

The elements of logic DBR are: 'Drum': it is the pass of the system, which determines its total productive capacity; therefore, it defines the rhythm of the production and restricts the capacity, that is, is the drum of the system, a time that said its rhythm of production; 'Buffer': it is the protection placed before the drum for to prevent the impact of the variability, as variation, machine in addition in the process time, problem of quality or lack of substance cousin to produce. It has three types of lung that can be used in this case: lung of time, inventory or of capacity; and 'Rope': it has the objective to signal the necessity of entrance of materials in the system, to feed the lung and the pass and to limit the amount of set free raw material for the plant. A reference model to realize the strategic management of productive capacity of the manufacturing integrating TOC and efficiency indicators can be found in Pacheco et al. (2012a).

\section{PROPOSITION OF STRATEGIES TO ELEVATE CAPACITY OF INTERNAL CONSTRAINTS}

From the literature review, intervention strategies related to the fourth step of the TOC (Raise), apply when the bottleneck is inside the factory, is when the total demand for a given product mix is greater than the capacity of the plant. As Antunes and Rodrigues, (1998), Umble and Srikanth (1990), Goldratt (1990), Sproull (2009), Dettmer (2001), Hayes et al. (2008), Scheinkopf and Moore (2004), Hopp and Spearman (2001) these are the main actions to increase the capacity of the internal restriction of the factory. It is worth noting that the application and analysis of strategies independent of the order they are presented in text and can be adopt her individually and independently or from a combination between them.

- Strategy 1: Eliminate all periods of time lost in the bottleneck. An hour lost on bottleneck is an hour lost in the whole system and being bottleneck should operate 24 hours a day.

- Strategy 2: Improved processing times per unit. Perform continuous improvement actions in the working methods and the optimum use of the potential of the equipment.

- Strategy 3: Deliver improvements in the power system engineer. The goal should be to synchronize the timing of food resources with the speed of processing of the resource itself, seeking continuous system flow. 
- Strategy 4: Improve the quality control system. The initiatives should ensure that there is no defective part is processed in the neck, which can be obtained by adopting a $100 \%$ inspection immediately before the bottleneck should also ensure that all part is that go through bottleneck Throughput (GOLDRATT, 1992; CORBETT, 1997) for managing the organization, is the production of defects and rework after the bottleneck is zero.

- Strategy 5: Making the contracting out or outsourcing of work from the bottle. In other words, implies subcontract or outsource part of production that was previously done by its neck in order to purchase additional capacity (UMBLE; SRIKANTH, 1990).

- Strategy 6: Buy additional capacity. You can obtain the following ways: buying new machine, hiring new workers to the neck, using overtime for workers in the neck or adding shifts to production.

- Strategy 7: Relocation of the operations previously performed in the neck for other non-bottleneck machines that are operating with a surplus of capacity. The goal this point is to divide the operation of the bottleneck in smaller suboperations and redistribute them.

- Strategy 8: Make improvements in the maintenance of machine bottleneck and critical system resources. The objective of working to improve the maintenance of machine bottleneck is to increase the coefficient of utilization (TEEP) and the availability (A) of the critical resources in manufacturing.

- Strategy 9: Conduct analysis and layout changes. At this point, it is suggested to apply the concepts of lean thinking mobile layout and simulate scenarios proposed using the technique of computer simulation to aid in decision making, apart from the results of the simulation.

- Strategy 10: Implement the algorithm Drum-Buffer-Rope (DBR) system. The use of the DBR aims to operate on the factory floor to the five steps of process improvement of TOC, synchronizes the system from the bottleneck and protects the capacity of the bottleneck using the buffer immediately prior to the drum.

- Strategy 11: Raise the TEEP of the resource bottleneck. His discussion is central to the capacity calculation because it determines the theoretical and 
not practical capacity of the equipment. The increase in TEEP can be done in the following ways:
a) Raise the $\mu 1$ : Index of Operational Time (ITO);
b) Raise the $\mu 2$ : Index of Operational Performance (IPO);
c) Raise the $\mu 3$ : Index of Approved Products (IPA).

- Strategy 12: Increase the availability (A) of the resource bottleneck. This strategy can be implemented as follows: MTFB raising and reducing the MTTR of the equipment.

- Strategy 13: Oriented approach to product development. The idea is to develop new products or components that would not bottleneck of the factory, aiming to exploit the gaps in the capacity of non-bottleneck resources.

- Strategy 14: Modify existing products or components in order to reduce the processing time on bottleneck resource factory. Joint action between the area of Process Engineering and Product Engineering Company seeking to modify the concept of products focusing on the bottleneck; tend to generate good which alter.

- Strategy 15: Conduct analysis and improvement of the bottleneck applying the subsystems and techniques of TPS. Suggest apply: Zero Defects, Standard Operation, SMED (Single-Minute Exchange of Die), Flow Synchronization and Continuous Improvement are good improvement strategies. The goal is to extend the TOC, the benefits that Lean approaches provide.

- Strategy 16: Conduct analysis of restriction from seven losses in the TPS. The combination of the elimination of seven losses in the operation can generate earnings capacity in the bottleneck. It is recommended that this analysis is made by a multidisciplinary group involving the operators of the processes analyzed.

- Strategy 17: Conduct analysis of improvement in the ergonomic point of view of the operation. Time and motion study, derived from scientific management are recommended.

- Strategy 18: Make improvements in the productive system as a whole. In this case indicates the application of the principles of synchronous manufacturing, based on nine OPT rules and derived from the five focusing steps of TOC. 
- Strategy 19: Evaluate the application of first principle of TOC that says to not to focus in the balancing of the capacities and yes to focus the synchronization of the flow. This principle elapses of that the capacity of the resources is finite and to the effect of the statistical fluctuations and the dependence between the resources.

- Strategy 20: Evaluate the application of second principle TOC that says the value marginal of the time in the resource bottleneck is equal to the rate of profit of the products processed for the bottleneck. That is, one hour earns in the pass represents one hour earns all in the system.

- Strategy 21: Apply the third principle TOC that says the marginal value of time in a resource bottleneck is not negligible. That is, the focus is the actions of improvement must be in the restriction of the system.

- Strategy 22: To consider the fourth principle of TOC that statements that the level of use of a resource pass is not controlled for the restriction of the system. In principle, the idea is that the decision on the use of non-bottleneck must be made by analyzing the resource bottleneck.

- Strategy 23: Apply the fifth principle of TOC that statement the resources must be used and not only activated. The use concept mentions the activation to it of resources that contribute positively for the performance of the company that is to generate profits for the Company.

- Strategy 24: Apply the sixth principle indeed the lot of transference does not need to be, and many times do not have to be, equal to the lot of process. The lot of process is the amount of product processed in a resource before the same it is moved to manufacture one another different product that is, after the execution of setup. Lot of transference is the amount of units that are removed and put into motion at the same time (in one it crowds) of a resource for the following resource. To use lesser lots of transference of what the lots of process present considerable advantages: it helps to keep the synchronization of the production, soon after the pass, how much lesser the used lot of transference lesser will be the total time of crossing of the products and how much lesser the lots of transference more quickly will be discovered the defects of product quality or parts. 
INDEPENDENT JOURNAL OF MANAGEMENT \& PRODUCTION (IJM\&P)

http://www.ijmp.jor.br

v. 5, n. 2, February - May 2014.

ISSN: 2236-269X

DOI: 10.14807/ijmp.v5i2.134

- Strategy 25: Apply the seventh principle that says the process batch should be variable. The process batch should be variable along the route of manufacture and over time. It is reasonable to assume that the lot in process can vary throughout the route of manufacture due to the impact of the statistical fluctuations of the system and the different capacities of the resources.

\section{CONCLUSION}

This article sought to achieve a set of strategies can be adopted to increase the capacity constraints in production systems, where the constraint is internal to the factory, from of the TOC, TPM and Lean. Was enumerated a set of 25 intervention strategies that contribute to the increased capacity of restriction in a manufacturing system. Is valid considering that the strategies listed before being applied in the real world, require the analysis of two important variables: time and investment required.

Antunes (1998) suggests that to reduce the preparation time, to improve the feed of the machines and avoid the time lost in the bottleneck typically require low investments. To extend that study suggested that: include in the discussion of the vision of Six Sigma methodology and Factory Physics, aiming to bring new analysis variables giving more robustness to propositions and include in the discussion of the remaining items of the TOC analysis as the VAT analysis and thinking process tools. For new researches in industrial manufacturing context, the starting point of alignment between three approaches to the production strategy can be found in Pacheco (2012b).

\section{REFERENCES}

ANTUNES JR., J. (1998) Towards a general theory of the case in production management: a discussion about the possibility of unifying theory of constraints and the theory that supports the construction of production systems with zero inventory. Thesis (Ph.D. in Business Administration). Post Graduate Program in Management of UFRGS, Porto Alegre, RS.

ANTUNES, J.A.V.; RODRIGUES, L. H. (1993) Theory of Constraints: an analysis of the actions of improvements necessary to raise the capacity constraints. Production, Porto Alegre, v. 3, n. 1, p. 73-86.

ANTUNES, J.; ALVAREZ, R.; KLIPPEL, M.; BORTOLOTTO, P.; PELLEGRIN, I. (2008) Sistemas de Produção: Conceitos e Práticas para Projeto e Gestão da Produção Enxuta. 1. ed. Porto Alegre: Bookman.

BETTERTON, C. E.; COX III, J. F. (2009) Espoused drum-buffer-rope flow control in serial lines: A comparative study of simulation models, International Journal of 
INDEPENDENT JOURNAL OF MANAGEMENT \& PRODUCTION (IJM\&P)

http://www.ijmp.jor.br

v. 5, n. 2, February - May 2014.

ISSN: 2236-269X

DOI: 10.14807/ijmp.v5i2.134

Production Economics, v. 117, p. 66-79, ISSN 0925-5273, http://dx.doi.org/10.1016/j.ijpe.2008.08.050.

BEVILACQUA, M.; CIARAPICA, F.E.; GIACCHETTA, G. (2009) Critical chain and risk analysis applied to high-risk industry maintenance: A case study, International Journal of Project Management, v. 27,pp. 419-432, ISSN 0263-7863,

BONAL, J. et al. Overall Fab Efficiency. Advanced Semiconductor Manufacturing Conference IEEEISEMI, 1996, p. 49-52.

CORBETT NETO, T. (1997) Contabilidade de ganhos: a nova contabilidade gerencial de acordo com a teoria das restrições. São Paulo: Nobel.

DETTMER, W. (2001) Beyond Lean Manufacturing:Combining Lean and the Theory of Constraints for Higher Performance. Goal System International. Port Angeles, WA, USA.

ED ROSE; ODOM, R.; DUNBAR, B.; HINCHMAN, J. (1995) How TOC \& TPM Work Together to Build the Quality Toolbox of SDWTs. IEEEKPMT - Electronlcs Manufacturing Technology Symposium. p.56-59.

GEORGIADIS, P.; POLITOU, A. (2013) Dynamic Drum-Buffer-Rope approach for production planning and control in capacitated flow-shop manufacturing systems, Computers \& Industrial Engineering, v. 65, p. 689-703, ISSN 0360-8352, GOLDRATT, E. M.; FOX E. R. (1987) The race. NY: The North River Press. GOLDRATT, E. M. (1990) The Haystack Syndrome. NY: The North River Press. GOLDRATT, E. M. (1991) A síndrome do Palheiro: Garimpando informações num oceano de dados. São Paulo: Educator.

GOLDRATT, E. M. (2009) Standing on the Shoulders of Giants - Production concepts versus production applications The Hitachi Tool Engineering example. In: Gestão \& Produção, v. 16, n. 3, p. 333-343.

HAAN, J.; NAUBS, F.; OVERBOOM, M. (2012) Creative tension in a lean work environment: Implications for logistics firms and workers, International Journal of Production Economics, v. 137, p. 157-164, ISSN 0925-5273.

HAYES, R.; PISANO, G.; UPTON, D.; WHELLWRIGHT, S. (2008) Production, technology and strategy: in search of competitive advantage. Porto Alegre: Bookman.

HOPP, W.; SPEARMAN, M. L. (2001) Factory Physics. Boston: Irwin.

JAYARAM, J.; DAS, A.; NICOLAE, J. (2010) Looking beyond the obvious: Unraveling the Toyota production system. International Journal of Production Economics. v. 128 , n. 1, p. 280-291.

LEE, JUN-HUEI.; CHANG, JIA-GING.; TSAI, CHIH-HUNG.; LI, RONG-KWEI. (2010) Research on enhancement of TOC Simplified Drum-Buffer-Rope system using novel generic procedures, Expert Systems with Applications, v. 375. p. 3747-3754.

LINHARES, A. (2009) Theory of constraints and the combinatorial complexity of the product-mix decision, International Journal of Production Economics, v. 121, p. 121-129. 
INDEPENDENT JOURNAL OF MANAGEMENT \& PRODUCTION (IJM\&P)

http://www.ijmp.jor.br

v. 5, n. 2, February - May 2014.

ISSN: 2236-269X

DOI: 10.14807/ijmp.v5i2.134

MABIN, V. J.; BALDERSTONE. S. J. (2000) The World of the Theory of Constraints: A Review of the International Literature. FL: St. Lucie Press.

MOORE, R.; SCHEINKOPF, L. (1998) Theory of constraints and lean manufacturing: friends or foes.

OHNO, T. (1997) The Toyota Production System: Beyond large scale production. Porto Alegre: Bokmann.

PACHECO, A. J. P. et al. (2012) Modelo de gerenciamento de capacidade produtiva: integrando teoria das restrições e o índice de rendimento operacional global (IROG). Produção Online, v.12, n. 3, p. 806-826, jul./set.

PACHECO, D. A. J. (2012b) Integrando a Estratégia de Produção com a Teoria das Restrições, Lean e Seis Sigma: uma abordagem metodológica. 2012. Dissertação (Mestrado em Engenharia de Produção e Sistemas)-Universidade do Vale do Rio dos Sinos, São Leopoldo.

PACHECO, D. A. J. et al. Balanceamento de fluxo ou balanceamento de capacidade: análise e proposições sistêmicas. Ahead to print in Gestão \& Produção, 2013.

PACHECO, D. A. J. Teoria das Restrições, lean manufacturing e seis sigma: limites e possibilidades de integração. Ahead to print in Revista Produção, 2014.

PERGHER, I.; RODRIGUES, L. H.;LACERDA, D. P. (2011) Discussão teórica sobre o conceito de perdas do Sistema Toyota de Produção: inserindo a lógica do ganho da Teoria das Restrições. Gestão \& Produção, v. 18, n. 4, p. 673-686.

ROSSI FILHO, T. A.; PERGHER, I.; LACERDA, D. P.; RODRIGUES, J. H. (2012) Aplicação do Processo de Pensamento da Teoria das Restrições para o desenvolvimento sustentável: Uma proposição teórica. Espacios. v. 33, n. 8.

ROTHER, M.; JOHN, S. (1998) Learning to See: Value Stream Mapping to add value and eliminate waste. Sao Paulo-SP, Brazil Lean Enterprise Institute.

SCHONBERGER, R. J. (2007). Japanese production management:an evolution with mixed results. Journal of Operations Management, v. 25, p. 403-419.

SHINGO, S. (1996a) The Toyota Production System: From the standpoint of production engineering. Porto Alegre: Bookman.

SHINGO, S. (1996b) Manufacturing Systems with Zero Inventory: The Shingo system for continuous improvement. Porto Alegre: Bookman.

SPROULL, B. (2009) The Ultimate Improvement Cycle - Maximizing Profits Through the Integration of Lean, Six Sigma, and the Theory of Constraints, CRC Press, Taylor \& Francis Group, Boca Raton, FL.

SEREMBU, J. F.; MELOY, F.; POSMONTIER, B. (2012) Learning from Business: Incorporating the Toyota Production System into Nursing Curricula. Nursing Clinics of North America, v. 47, n. 4, p.503-516, ISSN 0029-6465.

STAPLETON, F. B.; HENDRICKS, J.; HAGAN, P.; DELBECCARO, M. (2009) Modifying the Toyota Production System for Continuous Performance Improvement in an Academic Children's Hospital, Pediatric Clinics of North America, v. 56, p. 799-813, 
TOMINO, T.; PARK, Y.; HONG, P.; J. J. (2009) Market flexible customizing system (MFCS) of Japanese vehicle manufacturers: An analysis of Toyota, Nissan and Mitsubishi. International Journal of Production Economics, v. 118, n. 2, p. 375386.

UMBLE, M. M.; SRIKANTH, M. L. (1990) Synchronous Manufacturing: Principles for World Class Excellence. South-Western Publishing Company, Cincinnati, Ohio.

WANG, X.; CONBOY, K.; CAWLEY, O. (2012) "Leagile" software development: An experience report analysis of the application of lean approaches in agile software development, Journal of Systems and Software, v. 85, p. 1287-1299.

WATSON, K. J.;BLACKSTONE, J. H.; GARDINER, S. C. (2007) The evolution of a management philosophy: The theory of constraints, Journal of Operations Management, v. 25, p.387-402.

WOMACK, J. P.; JONES, D. T.; ROOS, D. (1990) The Machine That Changed the World. Harper Perennial, New York.

WOMACK, J. P.; JONES, D. T. (1996) Lean Thinking: Banish Waste and Create Wealth in Your Corporation. Simon \& Schuster, New York.

WONG, C.; ORTIZ, M.; TORCASIO, A.; RODRIGUEZ, E.; COLLADO, M. (2009) Estrategias para el mejoramiento de la gestión de mantenimiento usando la teoría de restricciones. Espacios, v. 30, n. 2, p. 22-32.

WU,HORNG-HUEI., CHEN, CHING-PIAO.; TSAI, CHIH-HUNG.; TAI-PING, TSAI. (2010) A study of an enhanced simulation model for TOC supply chain replenishment system under capacity constraint, Expert Systems with Applications, v. 37, p. 6435-6440. 